\title{
3-D Subsurface Geoelectrical Resistivity Imaging of Contaminant Plume From Cassava Processing Mill in Ozalla Area of Edo North, Nigeria
}

\author{
${ }^{1 *}$ EHILENBOADIAYE, JI; ${ }^{2}$ OZAH, EE \\ ${ }^{1}$ Department of Physics, University of Benin, Benin City, Edo State, Nigeria \\ ${ }^{2}$ National Institute of Construction Technology Uromi, Edo State, Nigeria \\ Email: manjohnel4luv@yahoo.com
}

\begin{abstract}
Electrical Resistivity Tomography (ERT) was used to map and detect the subsurface contaminant plumes from the cassava effluents in the various cassavas processing mill in Ozalla Area of Edo North, Edo State, Nigeria. The result from the 3D resistivity images shows clearly the distribution of the plumes from all the profile lines in the surveyed area. From the results it is evident that at a depth of $2.5 \mathrm{~m}-21.9 \mathrm{~m}$ with resistivity values between $6.2 \Omega \mathrm{m}-13.1$ $\Omega \mathrm{m}$ the plumes were observed. The results thus point out the need for environmental Education and proper management/location of cassava processing sites by the relevant agencies of Government.
\end{abstract}

\section{DOI: $\quad$ https://dx.doi.org/10.4314/jasem.v22i1.5}

Copyright: Copyright (ㄷ 2017 Ehileboadiaye and Ozah. This is an open access article distributed under the Creative Commons Attribution License (CCL), which permits unrestricted use, distribution, and reproduction in any medium, provided the original work is properly cited

Dates: Received 11 November 2017; received in revised form 14 December 2017; accepted 30 December 2017

Keywords: Geoelectrical, Mill, Contaminant Plume, Cassava effluent, Imaging

As observed by Begun et al., (2009), large quantities of pollutants have continuously been introduced into ecosystems as a consequence of urbanization and industrial processes. These pollutants can be biomagnified in the food chains, becoming increasingly dangerous to human beings and wildlife. Soil is one of the repositories for anthropogenic waste. Biochemical processes can mobilize them to pollute water supplies and impact food chains.

Heavy metals such as $\mathrm{Cn}, \mathrm{Cr}, \mathrm{Cd}, \mathrm{Ni}$, and $\mathrm{Pb}$ are potential soil and water pollutants. Globally, the problem of environmental pollution has begun to cause concern in most large cities since this may lead to geoaccumulation, bioaccumulation and biomagnifications in ecosystems. Contaminants in the environment are eventually deposited in soils in some form of a low solubility compound, such as pyrite (Huerta-Diaz and Morse, 1992) or sobbed on surfacereactive phases, such as Fe and Mn oxides (Cooper et al., 2005; Hamilton-Taylor et al., 2005). Lead (Pb) is the most common environmental contaminant found in soils. Unlike other metals, $\mathrm{Pb}$ has no biological role, and is potentially toxic to microorganisms (Sobolev and Begonia, 2008).

Its excessive accumulation in living organisms is always detrimental. Furthermore, $\mathrm{Pb}$ exposure can cause seizures, mental retardation, and behavioral disorders in human beings. Heavy metal exposure to human beings occurs through three primary routes namely inhalation, ingestion and skin absorption. All these occur in myriads of places including automechanic workshops. Generally, toxic metals cause enzyme inactivation, damage cells by acting as antimetabolites or form precipitates or chelates with essential metabolites. According to USDA (2000), acute (immediate) poisoning from heavy metals is rare through ingestion or dermal contact, but it is possible. Chronic problems associated with long-term heavy metal exposures are mental lapse (lead); toxicological effects on kidney, liver and gastrointestinal tract (cadmium); skin poisoning and harmful effects on kidney sand the central nervous system (arsenic). There is a link between long term exposure to copper and decline of intelligence in young adolescents (Lenntech, 2009).

Leachate plumes generated from cassava effluents can be inorganic chemicals similar to those inorganic contaminations from landfills, open wastes disposal sites, salt brines, acid spills and natural salt-water intrusions. Inorganic contaminations from cassava effluents, cemeteries, open waste disposal sites as well as salt brines, acids spills and natural salt-water intrusion are detectable by electrical methods because of their high values of specific conductance, the application of electrical resistivity tomography in tracking the plume from cassava effluents emanating from the processing of cassava which serves as 
Environmental pollution and contamination to ground water supply has led to this research work.

The aim of this research is to establish the reliability of using geophysical method in mapping contaminant plume of cassava processing mill location in Ozalla Area of Edo North.

\section{MATERIALS AND METHODS}

Location and Geological Setting of the Study Area: The study was carried out in Ozalla community were cassava is processed in the Northern part of Edo state, Nigeria (fig 1). Edo State is an inland State in central southern Nigeria. Its capital is Benin City. It was created from the defunct Bendel State on the $27^{\text {th }}$ of August 1991 and is located in the rain forest belt of Nigeria between Longitude 5" 42' and 6o 45'E and Latitude 5" $45^{\prime} \mathrm{N}$ and $7 " 35^{\prime} \mathrm{N}$.

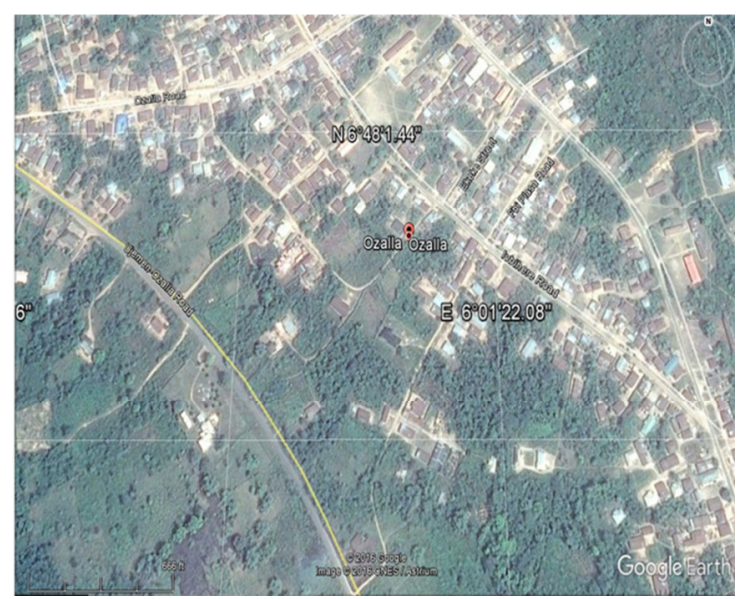

Fig 1: Aerial View of Ozalla Town (Source Google Earth)

It is bounded by Kogi State to north; to the east by both Kogi and Anambra States; to the South by Delta State and by Ondo State to the west. It has a total land mass/area of 19,281.93 square kilometers ad eighteen (18) Local Government Areas that make up the three (3) Senatorial Districts, namely Edo South, Edo Central and Edo North. Natural resources abound in the state and these include: hardwood and timber, limestone, marbles lignite crude oil, gold, clay, Kaolin, granite, amongst others.

The State is generally low-lying except in the northern part that is characterized by undulating hills. The geology of the study area is described in the geology of Niger delta. Niger delta is one of the ten major sedimentary basins of Nigeria.

The others are Abakaliki basin, Anambra Basin, Benue trough, Bida basin, Bornu-Chad basin, Dahomey basin, Gongola basin, Sokoto basin and
Yola trough. These onshore basins occupy about half the total area of Nigeria (Whiteman 1982). The basins are delineated by three main areas of basement complex. These are Western end of the Cameroun volcanic zone, Northern Nigeria massif and the eastern end of West African massif. The Niger Delta complex basin is situated on the Gulf of Guinea on the west coast of Central Africa.

Experimental: Electrical Resistivity Tomography (ERT) survey was carried out using the Wenner array to obtain the apparent resistivity of the various survey site because of its relativity sensitivity to vertical variations in the subsurface resistivity, moderate depths of investigation and general strong signal strength which is a preferred choice for the survey in a noisy site.

A minimum electrode separation of $(5 \mathrm{~m})$ and interlines spacing $10 \mathrm{~m}$ were used. In each site of investigation, the field survey was in a square grid format, such that the parallel lines are all the same of $100 \mathrm{~m}$ each. The 2D apparent resistivity data for each of the Wenner arrays were collated to 3D data and inverted using a full 3D inversion code RES3DINV.

After inversion with RES3DINV the 3D inverted data was extracted and volume rendering image processing technology Voxler 3D software was used to transforms the inverted data into understandable visual models. With Voxler's extensive 3D modeling tools, it is easy to visualize multi-component data for geologic and geophysical models, contaminant plumes, borehole models, or ore body deposit models. Also from the 3D block model, the flow chart/pattern of the contaminant leachate plumes were modeled out in layers.

\section{RESULTH AND DISCUSSION}

Figure 2 is the collated 3D images obtained in ozalla community from the cassava processing mill which clearly shows all the eight profiles in 3D format, collated from $2 \mathrm{D}$ to $3 \mathrm{D}$. The resistivity ranges from 1 $\Omega \mathrm{m}$ to $4524 \Omega \mathrm{m}$ with a depth of $21.9 \mathrm{~m}$, to the last layer. The top layer from the collated $3 \mathrm{D}$ imaging is characterize by relatively high resistivity values from the beginning of the profile in the top part of the profiles, the contaminated area can been seen clearly at the $40 \mathrm{~m}$ of the spread of the profiles where the cassava processing machine is cited in the third layer.

The dark blue colour at the 3rd layer with a resistivity of $6 \Omega \mathrm{m}-8 \Omega \mathrm{m}$ and a depth of $5 \mathrm{~m}-13 \mathrm{~m}$ shows the leachate plume indicated by an arrow head in the last three layers. It will be notice at the midpoint of the 
spread where all the debris from the leach material has settled has a low resistivity values which indicate the contaminated zone. The top and last layers from the collated 3D images have a high resistivity value which can be interpreted as a mixture of compacted clay sediment and lateritic soil as a result of the low resistivity values seen at the middle to the last layer, there is indication of presence of high ionic content; hence there is increase in conductivity of the area. Figures 3 and 4 shows the images of the top and bottom view of the 3D block obtained in the study area which show continues flow of the leachate plume down to the last depth of investigation. Figure 5 is the various layers with depth from the 3D block obtained from the study area.
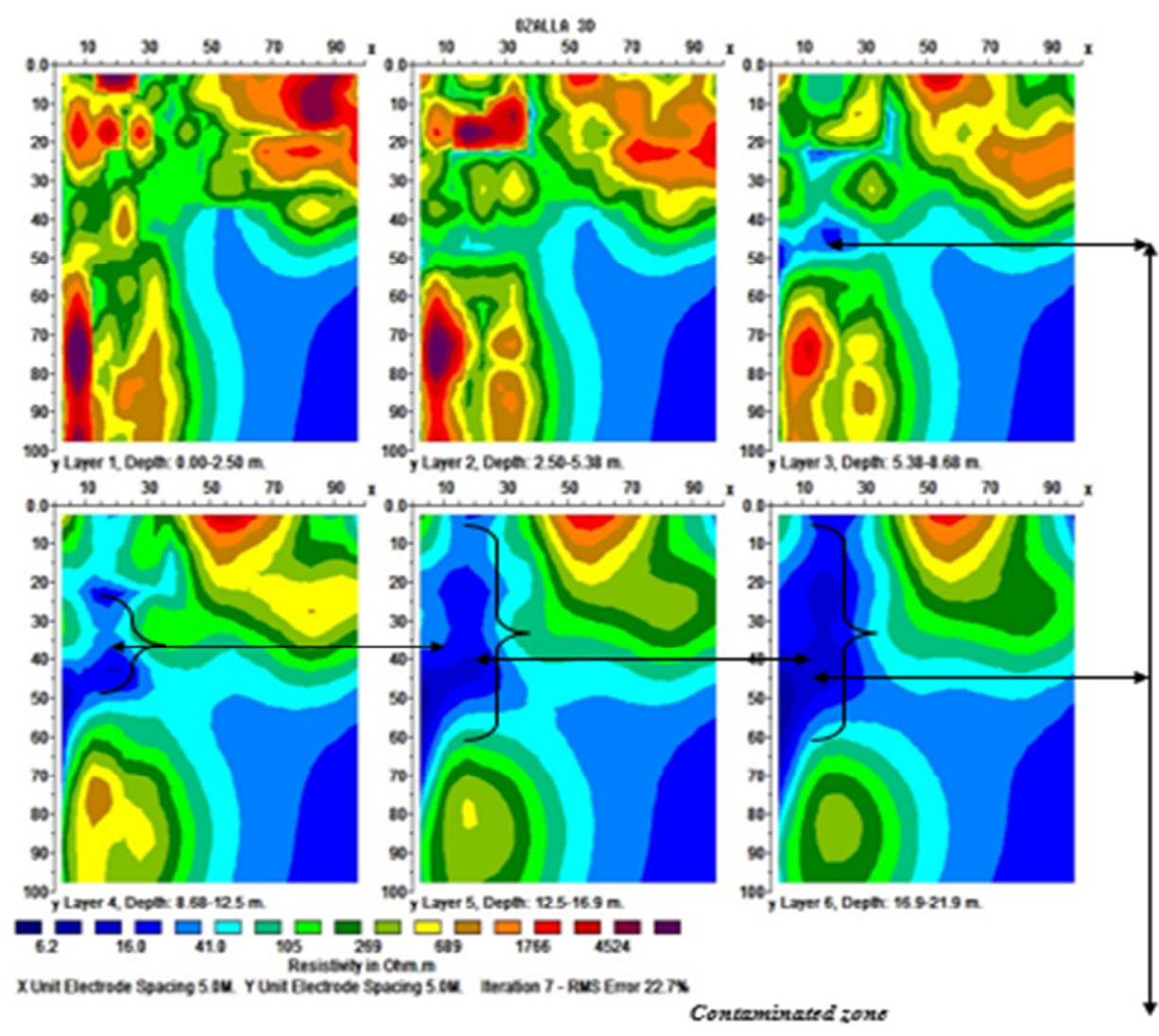

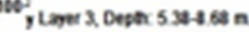

Fig 2: Collated Inverted 3D slice obtained from the study area

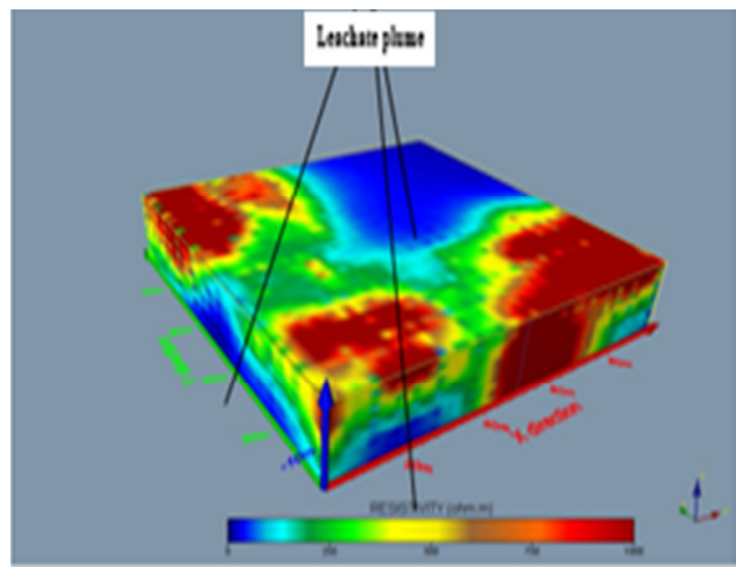

Fig 3: The block view of the 3D block obtained from the study area

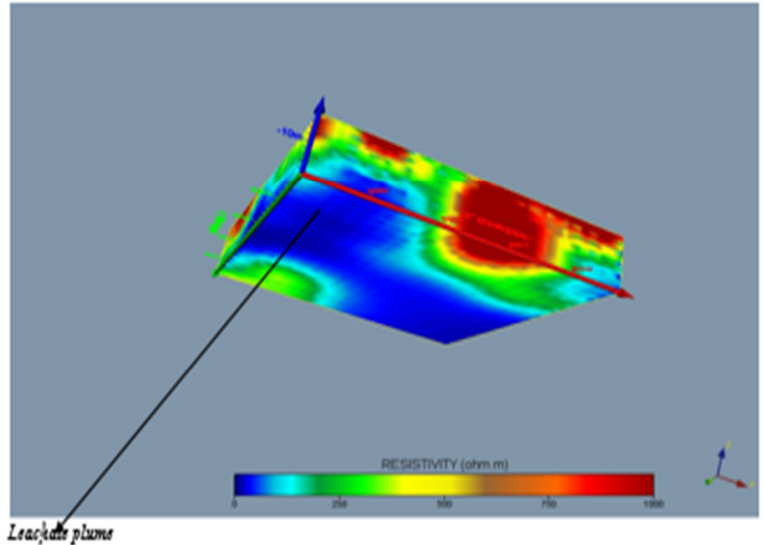

Fig 4: The bottom surface view of the 3D block obtained from the study area 


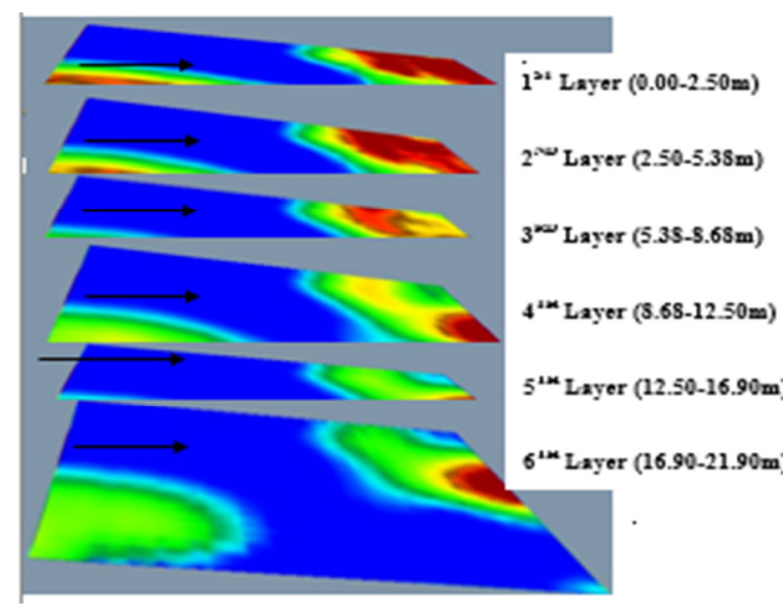

Fig 5: 3D layers with depth of the contaminant leachate plume from the study area

Conclusion: The geoelectrical investigations performed at Ozalla community in Edo North, Edo State, Nigeria from Cassava Processing mill allowed us to indicate some of the permeable zones where the infiltration of contaminations occurs. The results from the ERT clearly show that at a depth of $2.5 \mathrm{~m}-21.9 \mathrm{~m}$ with resistivity values of $6.2 \Omega \mathrm{m}-13.1 \Omega \mathrm{m}$ the plumes were delineated. Under favorable hydrological and geological conditions, the plumes delineated will slowly migrate into the aquifers.

Acknowledgement: The authors appreciate God for knowledge and the Ozalla community.

\section{REFERENCES}

Begun, DJ; Holloway, AK; Stevens, K (2009). Population genomics: whole-genome analysis of polymorphism and divergence in drosophila simulans. PLoS Biol. 5:e310.
Cooper, DF; Grey, S; Raymond, G; Walker, P (2005). Project Risk Management Guidelines: Managing Risk in Large Projects and Complex Procurements. 1st Edn. John Wiley and Sons Ltd., Chichester, England, ISBN: 0-470-022817.

Huerta-Diaz, MA; Morse, JW (1992). Pyritization of trace metals in anoxic marine sediments. Geochim. Cosmochim. Acta 56, 2681e2702. http://dx.doi.org/

$10.1016 / 0016-$ 7037(92)90353-K

Hamilton, AJ; Taylor, IR (2005) Distribution of foraging water birds throughout the Lake Borrie ponds at theWestern Treatment Plant, Victoria (Australia). The Victorian Naturalist, 122, 6878.

Lenntech (2009) Iron in groundwater. Lenntech water treatment and purification holding B. V, Rotter damseweg, Netherlands

Sobolev, D; Begonia, M (2008). Effects of heavy metal contamination upon soil microbes: Leadinduced changes in general and denitrifying microbial communities as evidenced by molecular markers. Int. J. Environ. Res. Public Health, 5: 450-456

U.S. Department of Agriculture, U.S. Department of Health and Human Services. (2000).Nutrition and Your Health: Dietary Guidelines for Americans (5th ed.) (Home and Garden Bulletin No 232).

Whiteman, A (1982). Nigeria: Its Petroleum Geology, Resources and Potential: London, Graham and Trotman, 394 p 56. 